\title{
Secondary multifocal osteosarcoma developing on the background of bone infarct
}

\author{
Ali Kemal Sivrioglu, Serkan Aribal, Hakan Onder
}

Radiology, Okmeydanı Education and Research Hospital, Istanbul, Turkey

Correspondence to Dr Hakan Onder, drhakanonder@hotmail.com

Accepted 12 April 2017

\section{DESCRIPTION}

A 49-year-old-man presented to orthopaedics clinic with complaint of recently growing thigh pain. $\mathrm{He}$ had a history of oral and inhaler forms of steroid usage for asthma and allergy on his background. X-ray examination of the left femur showed medullary lytic lesions localised in distal diaphysismetaphysis causing cortical destruction (figure 1). Contrast-enhanced MRI revealed medullary bone infarcts in distal diaphysis-metaphysis of the distal femur and proximal tibia bilaterally (figure 2). In this infarct area, there were multiple lesions causing cortical destructions with soft tissue components, and showing prominent enhancement on postcontrast images. The largest one is measured $4 \times 2.5 \mathrm{~cm}$. Multiple smaller lesions which were presenting

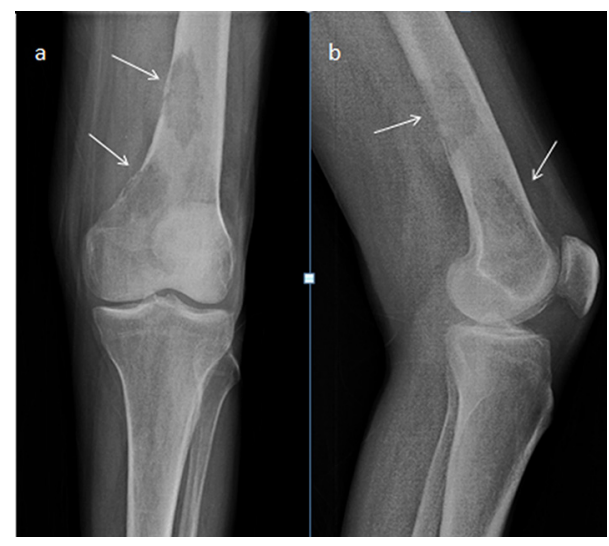

Figure 1 (A, B) X-ray examination of the left femur showed the medullary lytic lesions (arrows) localised in distal diaphysis-metaphysis causing cortical destruction.

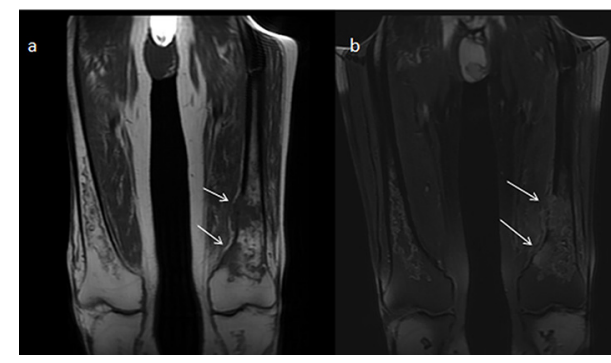

Figure 2 T1-weighted (A) and T2-weighted fat saturated (B) MRIs reveal medullary bone infarcts in distal diaphysis-metaphysis of the distal femur and proximal tibia bilaterally. In this left infarct area, there are multiple lesions (arrows) causing cortical destructions with soft tissue components and the largest one is measured $4 \times 2.5 \mathrm{~cm}$. similiar imaging characteristics without soft tissue components were also seen. Histological evaluation revealed the diagnosis of osteosarcoma.

Secondary osteosarcoma is the term referred to osteosarcomas developing on the background of conditions like Paget's disease, fibrous dysplasia and bone infarct. Osteosarcomas developing secondarily on the ground of bone infarcts are quite rare in this group. ${ }^{1}$ Infarcts can be seen in the diaphysis, metaphysis or epiphysis in long bones. Epiphyseal bone infarcts can be recognised and treated at an early stage since they are usually symptomatic. However, diaphyseal and metaphyseal infarcts may not get an early diagnosis since they can be asymptomatic for a longer time. Therefore, neoplasia development on the background of infarcts frequently occur in the medullary cavity of diaphysis. ${ }^{2}$ The most common malignancies arising on this ground are pleomorphic undifferentiated sarcoma and osteosarcoma.

\section{Learning points}

- Secondary osteosarcoma is the term referred to osteosarcomas developing on the background of conditions like Paget's disease, fibrous dysplasia and bone infarct.

- Epiphyseal bone infarcts can be recognised and treated at an early stage since they usually cause symptoms. However, diaphyseal and metaphyseal infarcts may not get an early diagnosis since they can be asymptomatic for a longer time.

- The most common malignancies arising on the background of bone infarct are pleomorphic undifferentiated sarcoma and osteosarcoma.

Contributors AKS,SA and HÖ conceived the paper. AKS and SA assembled tha case history from hospital records. AKS and SA participated in the writing of the paper. $\mathrm{HÖ}$ approved the final version.

Competing interests None declared.

Patient consent Obtained.

Provenance and peer review Not commissioned; externally peer reviewed.

(C) BMJ Publishing Group Ltd (unless otherwise stated in the text of the article) 2017. All rights reserved. No commercial use is permitted unless otherwise expressly granted.

\section{REFERENCES}

1 Domson GF, Shahlaee A, Reith JD, et al. Infarct-associated bone sarcomas. Clin Orthop Relat Res 2009;467:1820-5.

2 Desai P, Perino G, Present $D$, et al. Sarcoma in association with bone infarcts. Report of five cases. Arch Pathol Lab Med 1996;120:482-9. 
Copyright 2017 BMJ Publishing Group. All rights reserved. For permission to reuse any of this content visit http://group.bmj.com/group/rights-licensing/permissions.

BMJ Case Report Fellows may re-use this article for personal use and teaching without any further permission.

Become a Fellow of BMJ Case Reports today and you can:

- Submit as many cases as you like

- Enjoy fast sympathetic peer review and rapid publication of accepted articles

Access all the published articles

- Re-use any of the published material for personal use and teaching without further permission

For information on Institutional Fellowships contact consortiasales@bmjgroup.com

Visit casereports.bmj.com for more articles like this and to become a Fellow 